\title{
Conflict management impact on the employee productivity
}

\author{
Nino Paresashvili ${ }^{1 *}$, Teona Maisuradze ${ }^{2}$, Badri Gechbaia ${ }^{3}$, Lidija Weis $^{4}$, and Viktor Koval ${ }^{5}$ \\ ${ }^{1}$ Ivane Javakhishvili Tbilisi State University, 1 Ilia Chavchavadze Avenue, Tbilisi 0179, Georgia \\ ${ }^{2}$ Georgian National Univeristy, 9 Tsinandali Street, Tbilisi, Georgia \\ ${ }^{3}$ Batumi Shota Rustaveli State University, 35/32 Ninoshvili/Rustaveli str., Batumi 6010, Georgia \\ ${ }^{4}$ Ljubljana School of Business, Tržaška cesta 42, SI-1000 Ljubljana, Slovenia \\ ${ }^{5}$ National Academy of Sciences of Ukraine, 54 Volodymyrska str., 01030 Kyiv, Ukraine
}

\begin{abstract}
Conflict management is one of the major skill that has a significant influence on the tasks employee have to perform daily bases. Conflict is unavoidable in daily routine of the organizations. Its importance is increased in the developing countries like Georgia as external factors make people to work in more unpredictable situations. This article is based on the research conducted in Georgia, shows main challenges, trends and understanding of conflict management, shows results and offers recommendations how to make employees more productive by managing it effectively. Objectives: This study aimed to evaluate main challenges of conflict management, its impact on employee and organization productivity in Georgia, make conclusions and give recommendations to managers and employees how to deal with the conflict situations and improve constructive outcomes. Other factors influencing productivity connected to conflict management were also investigated. Results: Results has shown that conflict management understanding is quite low in Georgian organizations, as well as the constructive and destructive outcomes of it. Reasons of conflict is mainly improper distribution of functions and duties. Employees prefer to use collaborating style for conflict resolution.
\end{abstract}

\section{Introduction}

Conflict in organizations was always under interest of researches and its interest has not reducing till now. This issue is actual with the same intensity for small, middle and large organizations. Contemporary working style needs understanding it from today's view, moreover in the period of pandemic. As per the Leslie A. DeChurch and Katherine L. Hamilton, 2007, conflicts can be relationship based and task based [1]. Conflicts of interests arise in group scarcity of freedom, position and resources [2]. Employees, who have different personality, have different attitude towards organizational conflicts. As a result they have different behavior during conflicts. For the employees both the personality

\footnotetext{
*Corresponding author: nino.paresashvili@tsu.ge
} 
and the situational factors are essential. But there are people who are inflexible in organizational conflicts. It's important to respect and consider the motives of their behavior in order to control them during conflict process [3]. Conflict is thus endemic despite the best of management practices in organizations and manifests in various forms as an intrinsic and unavoidable feature of employment relationship [4].

\subsection{Conflict management}

Conflict management is a skill any organization requires, as no organization actually exist without the existence of conflict. The managing organizational conflict is the general framework of the entrance and comprehensive treatment by which means that depend on the resolution of problems and disputes [5]. Conflicts have 3 possible ending: the loss - the loss, and loss - win - win - win [5]. Conflict management tactics positively moderate the relationship between task conflict and performance [1]. As mentioned above, conflict can be task or relationship based. Both of them has significant effect on the employee productivity and organizational results.

Conflict management impact on the organizational performance, was studied in Bangladesh also, by Md. Abu Taher, Anupam Kumar Das and Md. Sharfuddin Rashed in 2008 [7]. Study participants were enterprise employees. This study showed that decent environment at workplace plays a positive impact on OP. The practices of CMS improve OP through maintaining decent environment at workplace. The findings showed that CMS practices tend to establish a decent environment which leads to better OP. This study demonstrated that by choosing the proper way of CMS, organizations can have better outcomes.

Beryl Akoth Olang, in 2017 has conducted the study based on the Case of Stima Sacco Society Limited [7]. The findings led to a conclusion that organizational performance is influenced by innovative strategies, continuous performance monitoring programs, and the frequency of task conflicts. Innovation is a significant component of conflict management strategies in Stima Sacco Society Limited. Effective conflict management strategies are associated with improved performance and lower costs in Stima Sacco Society Limited.

Thus, based on the researches above, conflict management make a significant impact on the employee productivity. Same results were shown by the study, conducted in Georgia, which we will discuss further in next part of the article.

\section{Research findings}

The study was conducted in Georgia. Total 550 respondents were participated in the study. $55 \%$ of the respondents were from public organizations and $45 \%$ - from the private organizations. About $80 \%$ from the respondents have been working under the present employer more than 3 years, which makes their evaluation of the company processes more reliable. Only $17 \%$ of the total respondents have managerial positions in the organizations. Comparing other studies given in the paper, Georgian employees consider the main reason of the conflict is related to the improper distribution of functions and duties (Figure 1). 


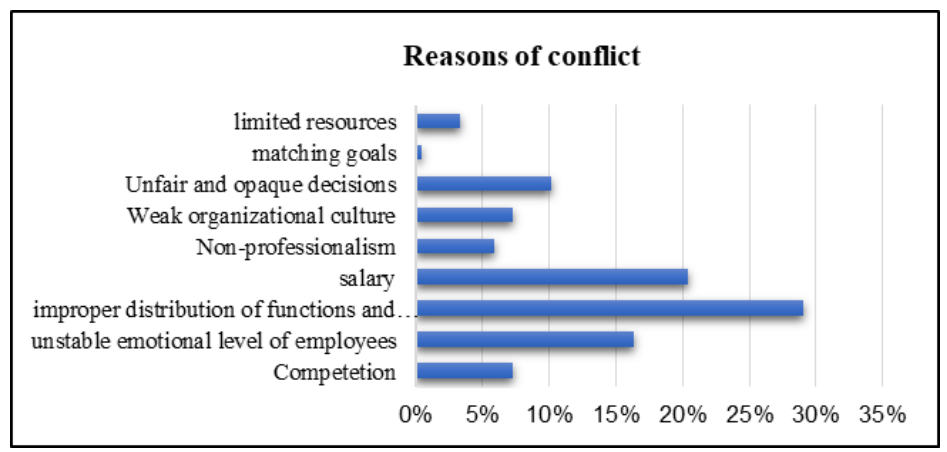

Fig. 1. Reasons of conflict in Georgian companies

Only $5 \%$ considers resource limitation as the source of conflict. As it was predictable due to the socio-economic level of the Country and restrictions related to Corona Virus, salary and non-stable emotional level of the employees are on the second and third places $(20 \%$ and $16 \%)$. A lot of organizations had to decrease the staff and/ or salaries. Salary level is major challenge for developing countries and for Georgia especially.

People hardly manage to live and prove for the families minimal living conditions. Only some offer to have a social life too. In today's world, after closing so many businesses and decreasing jobs, emotional stability of the people get worse. It makes for organizations and managers more challengeable to manage conflict situations. They need more effort to use conflict management skills to manage emotionally unstable people and achieve not the better but the previous quality outcomes [8-9].

Socio-psychological environment is stable only about half of the respondent. For the other half of the respondents it means workplace with high probability of conflict. This idea is supported by the frequency of conflict in the Organizations. (Table 1).

Table 1. Conflict frequency in Organizations in Georgia.

\begin{tabular}{|l|c|}
\hline \multicolumn{1}{|c|}{ Frequency } & \% \\
\hline Very frequently & 5 \\
\hline Periodically & 24 \\
\hline Rarely & 41 \\
\hline Almost never & 25 \\
\hline It is hard to answer & 5 \\
\hline
\end{tabular}

Understanding conflict management is one of the major challenge in Georgian organizations. Thus, conflicts are not managing in the way to bring good outcomes for the organization. Constructive understanding of conflict is very low. It causes low productivity level of workforce. About $60 \%$ of the Employees has neutral attitude towards the conflict and for $32 \%$ conflicts are negative. Only $9 \%$ sees the importance of the conflicts.

About managing the conflict, in $78 \%$ they can be managed, in $22 \%$ cases conflict situations cannot be or is hardly handled. In $37 \%$ of the organizations, there are no regulation methods of the conflicts. These are quite important parts, which can cause delay of desirable productivity and organizational outcomes.

It's crucial to deep into the situations where conflicts take place and understand the ways managing and solving it. In Georgian organizations, conflict type mostly defines the solution. In 59\% cases, conflict participants are solving conflict themselves, managers are 
involved in the process only in $40 \%$ cases. It underlines the low involvement of managers in conflict resolution and seems to have negative effect on the productivity. Conflict resolution is achieved mostly by collaborating (Figure 2). Next comes compromising with $8 \%$ and competing is the strategy, which Georgian employees using least.

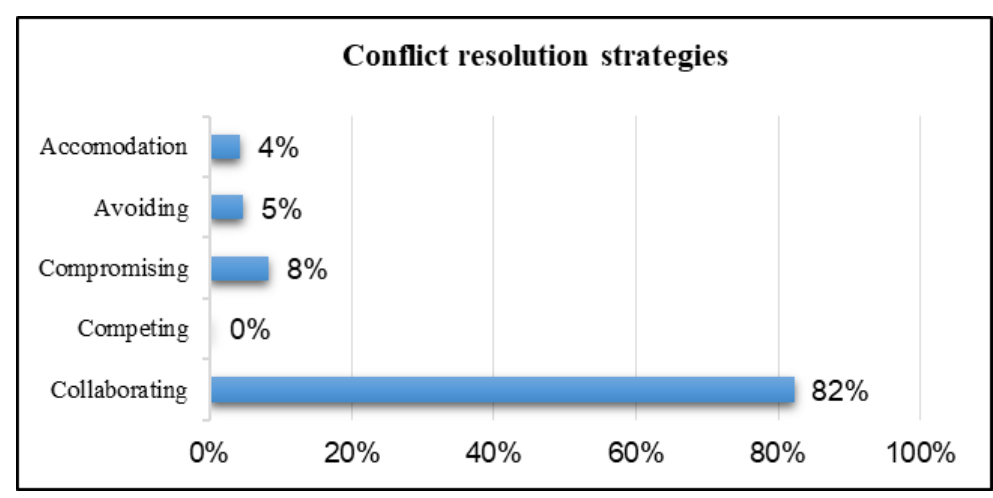

Fig. 2. Conflict resolution strategies in Georgian companies.

As it is known, conflict can have constructive and destructive impact on the organizations. Conflict management professionals should pay a special attention to avoid destructive results of the conflict as it can decrease productivity not only workforce, but worse organizational outcomes at all. In Georgia the Most destructive outcomes conflict can cause are: deterioration of personal relations, creating a tense work environment in the organization and leaving the job by the employee. In $8 \%$ cases it can even weaken the organization (Figure 3).

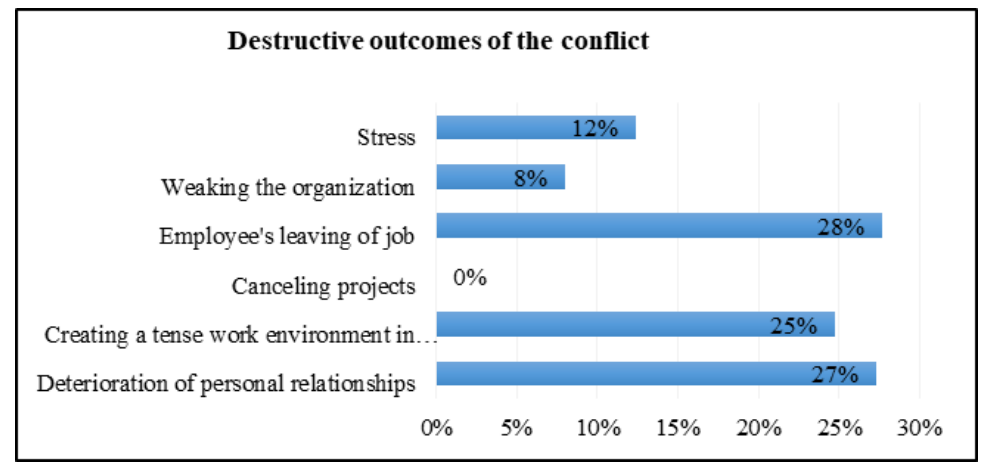

Fig. 3. Destructive outcomes of the conflict in Georgian companies.

As managers need to develop conflict management skills in Georgia and understanding conflict managements is on the low level, the destructive results given in figure 3 , are logical. When Managers don't manage conflict properly, tense working environment takes place in the organization, which causes to deterioration of relationships within the organization and is $28 \%$ of cases conflict participants choose to leave the organization at all.

Surprisingly, despite all the above mentioned, our respondents see and feel constructive outcomes of the conflict as well. Thus, it shows, conflict can have positive impact on the organization outcomes even it is not managing properly. In organizations in Georgia, the most spread positive outcome is regulation of outcomes (54\%). Observing of this result can give an idea, that when conflict takes place in the organization, it is not managed and conflict participant party leaves the organization, this automatically can cause the 
regulation of the relationships [10]. Other interested parties probably will support the winner party, which has stayed in the organization. In conclusion, this positive outcome related to improving relationships, needs more deep study. Next constructive outcome relieve tensions, can be discussed with the same logic and can have the same explanation. The other outcomes with quite low percentages (Figure 4) reinforces the idea discussed in this paragraph.

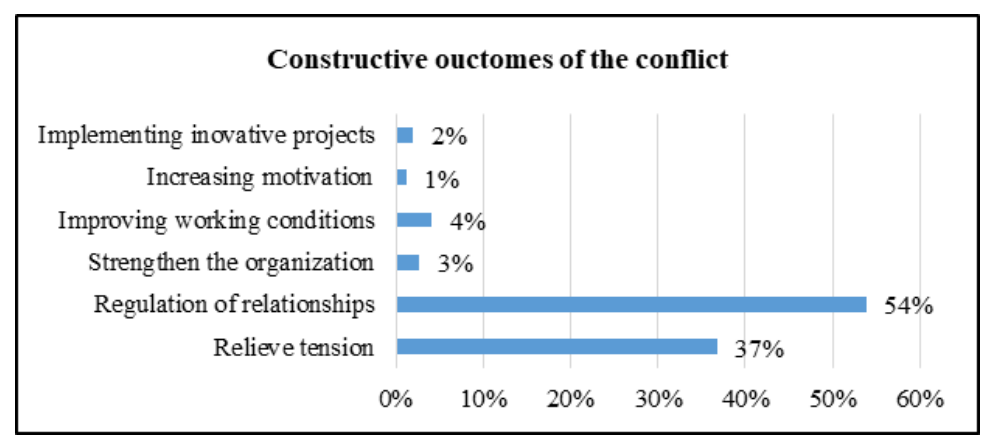

Fig. 4. Constructive outcomes of the conflict in Georgian companies

From Employees point of view, during the conflict process they try to compromise $(49 \%)$ and try to prove their truth (37\%). Considering the nature temper of Georgian people it is not surprising that from 550 respondents, no one agree with the views of opponent $(0 \%)$. But they prefer $(70 \%)$ to solve the conflict situations with democratic approaches, but $11 \%$ thinks autocratic style is required.

\section{Conclusions}

The conflict is a normal societal event. It is characteristic of every social system and becomes process and tool of humans' relationships. Relationship management is also an important skill for conflict resolution. The human, as well as society, can't be absolutely perfect, ideal and deprived of conflict. Disharmony, opposition and conflict are eternal and inevitable components of societal development. Thus, every organization has conflict and managing quality of it impacts on the employee performance and accordingly, on the organizational outcomes.

Developing countries has more challenges in managing the conflict in the context of achieving better productivity level. The study, conducted in Georgia in 2020, has shown that conflict understanding is quite low here. Responses of the respondents were similar to the responses each person can answer without any knowledge about the conflicts. Based on the results, managers are not involved in the conflict management. Employees try to use collaborative style. They are asking rarely managers to help. It causes, that conflict party, who loses the conflict, leaves the organization. When conflicting party is not in the organization, situation becomes stable, calm and predictable. This are very important findings, as this can be the main reason organization does not achieve its desirable outcomes. As it is proved by many researches and there is no more discussion, that employees are the most valuable asset for the organization, if situation continue like this, organization will lose its talents and productivity will decrease. The constructive outcomes of the conflicts, which the study has shown, can be caused, due to the leaving of conflict party.

Recommendations from this can be following: Organizations (Managers) should pay more attention on the conflict phenomena, they should increase qualification and 
gain/improve skills related to conflict management. Also, there can be conducted trainings about the conflict and its constructive and destructive outcomes. Conflict resolution by a third party through dispute resolution or direct dialogue is one of the most effective means. But should be considered that, every organization has specific style, specific rules, policy and situations which can not be combine in general rules. All this knowledge should be used in daily routine at the workplace. This will increase both the performance and the productivity of the employees and will be reflected on organizational outcomes positively.

\section{References}

1. L.A. DeChurch, K. L. Hamilton, Effects of Conflict Management Strategies on Perceptions of Intragroup Conflict. Group Dynamics: Theory, Research, and Practice, 11, 66-78 (2007)

2. V. Koval, Y. Polyezhayev, and A. Bezkhlibna, Communicative competences in enhancing of regional competitiveness in the labour market. Baltic Journal of Economic Studies 4, 105 (2019)

1. N. Paresashvili, T. Maisuradze, Mechanisms of organizational conflict resolution in Georgia. Journal of International Economic Research 3, 69-76 (2017)

2. O. Long, Impact of Workplace Conflict Management on Organizational Performance: A Case of Nigerian Manufacturing Firm, J. Manag. Strat. 6, 83 (2015)

3. A. A. S, AL-Shourah, The Impact of Conflict Management on Organizational Effectiveness (A Case Study: Ministry of Higher Education of Jordan). European Journal of Business and Management 7, 36 (2015)

4. T. L. Simons, R. Peterson, S. Randall., Task Conflict and Relationship Conflict in Top Management Teams: The Pivotal Role of Intragroup Trust, Journal of Applied Psychology 85(1), 102-111 (2002)

5. Md. A. Taher, A. K. Das and Md. Sh. Rashed, Conflict Management and Its Impact on Organizational Performance: A Study on Some Industrial Enterprises in Bangladesh, The Chittagong University Journal of Business Administration 23, 9-31 (2008)

6. O. Henry, Organisational Conflict and its Effects on Organisational Performance. Research Journal of Business Management 3, 16-24 (2009)

7. B. A. Olang, The influence of conflict management on organizational performance: a case of Stima Sacco society limited (United States International University Spring, 2017)

8. H. Bukanov, A.Kolesnyk, O. Tashkinova, V.Kotlubai, V. Koval, Social marketing in public administration of social service institutions. Revista Genero \& Direito 8 (6), 457-468 (2019)

9. O. Luchaninova, V. Koval, H. Deforzh, L. Nakonechna, O. Golovnia, Formation of communicative competence of future specialists by means of group work. Espacios $\mathbf{4 0}$ (41), 11 (2019)

10. M.Petrova, V. Koval, M.Tepavicharova, A. Zerkal, , A. Radchenko, N. Bondarchuk, The interaction between the human resources motivation and the commitment to the organization. Journal of Security and Sustainability Issues 9(3), 897-907 (2020). https://doi.org/10.9770/jssi.2020.9.3(15) 